\title{
Effect of Fly Ash on the Compressive Strength of Green Concrete
}

\author{
Sheeraz Ahmed Chandio \\ Department of Civil Engineering \\ Quaid-e-Awam University of \\ Engineering, Science \& Technology \\ Nawabshah, Pakistan \\ sheerz.ahmed030@gmail.com
}

\author{
Bashir Ahmed Memon \\ Department of Civil Engineering \\ Quaid-e-Awam University of \\ Engineering, Science \& Technology \\ Nawabshah, Pakistan \\ bashir_m@hotmail.com
}

\author{
Mahboob Oad \\ Department of Civil Engineering \\ Quaid-e-Awam University of \\ Engineering, Science \& Technology \\ Nawabshah, Pakistan \\ engrmahboob04@gmail.com
}

\author{
Faraz Ahmed Chandio \\ Department of Civil Engineering \\ Quaid-e-Awam University of Engineering, Science \& \\ Technology \\ Nawabshah, Pakistan \\ farazahmedchandio04@gmail.com
}

\author{
Muhammad Usama Memon \\ Department of Civil Engineering \\ Quaid-e-Awam University of Engineering, Science \& \\ Technology \\ Nawabshah, Pakistan \\ usama.memon9344@gmail.com
}

\begin{abstract}
This research paper aims at investigating the effects of fly ash as cement replacement in green concrete made with partial replacement of conventional coarse aggregates with coarse aggregates from demolishing waste. Green concrete developed with waste materials is an active area of research as it helps in reducing the waste management issues and protecting the environment. Six concrete mixes were prepared using 1:2:4 ratio and demolishing waste was used in equal proportion with conventional aggregates, whereas fly ash was used from $0 \%-10 \%$ with an increment of $2.5 \%$. The water-cement ratio used was equal to 0.5 . Out of these mixes, one mix was prepared with all conventional aggregates and was used as the control, and one mix with $0 \%$ fly ash had only conventional and recycled aggregates. The slump test of all mixes was determined. A total of 18 cylinders of standard size were prepared and cured for 28 days. After curing the compressive strength of the specimens was evaluated under gradually increasing load until failure. It is observed that $5 \%$ replacement of cement with fly ash and $50 \%$ recycled aggregates gives better results. With this level of dosage of two waste materials, the reduction in compressive strength is about $11 \%$.
\end{abstract}

Keywords-green concrete; recycled aggregates; demolishing waste; fly ash; compressive strength

\section{INTRODUCTION}

The research of finding alternatives or partial replacements of concrete ingredients is active, aiming at minimizing the environmental impact of concrete making and increasing the strength of the final concrete. The management of demolishing waste poses a serious problem, and this is a reason why it has been tried as coarse aggregates in new concrete. However, due to the age of concrete and old mortar adhered affects, the properties of aggregate and produced green concrete (concrete made with recycled aggregates from demolishing waste), particularly strength, are reduced and ways of mitigating this problem constitute an active research area. Recent developments on use of waste, its processing to develop coarse aggregates of required size, etc. have been presented in [1]. Environmental effects of green concrete [2] and green concrete towards sustainable environment [3] have also been studied. The scatter in published results of using waste shows that more work is required in the area to develop confidence in its practical use.

Fly ash is a very fine powder which is a combustion byproduct. Large volumes of this waste are generated every year posing a serious environmental problem. To reduce the waste to some extent, it may be used as pozzolanic (siliceous and aluminous) material, replacing cement in concrete. With the addition of water it reacts with calcium hydroxide and produces cementitious compounds. The use of fly ash in concrete as sustainable material has been reviewed in [4-7]. Authors in [8] used fly ash to develop concrete without increasing $\mathrm{CO}_{2}$ emissions. They also proposed stainless steel as reinforcement and a cladding system for better durability. The use of fly ash in conventional high strength concrete has been studied in [9]. From the test results the authors observed an increase in strength and a reduction in sorptivity at 28-day curing. Authors in [10] used $20 \%, 40 \%$ and $60 \%$ replacement of cement by fly ash to develop M15, M20, and M25 concrete. After studying the basic and strength properties of concrete, the acquired curves can be utilized to determine the dosage of fly ash for a required strength of the concrete. Authors in [11] studied the use of fly ash as engineered cementitious composite in high volumes to investigate micromechanics properties. They concluded that the use of the fly ash increases tensile strain capacity. However, the dosage of fly ash depends on compressive strength. In a research attempt to develop cement 
free concrete, authors in [12] used fly ash with alkaline solutions to develop mix design standards. To justify their proposal, the authors developed specimens and studied the properties of concrete. The comparison of the results with conventional concrete's shows good correlations between the two sets. Authors in [13], based on laboratory investigations on the use of fly ash from $10 \%$ to $30 \%$ by volume of cement, argued that the use of fly ash has a negative impact on concrete's compressive strength. Moreover, the use of fly ash in a percentage up to $20 \%$ results in increase in tensile strength and density. Authors in [14] on the other hand developed M20 grade concrete with $0 \%-20 \%$ fly ash with increment of $5 \%$. Test results of 7- and 28-day cured samples showed improvement in terms of strength and durability. Authors in [15] used Rice Husk Ash (RHA) in concrete and concluded that the compressive and tensile strength of the concrete specimens increased $11.8 \%$ and $7.31 \%$, respectively when $10 \%$ RHA was used and after 28 days of curing. Authors in [16] used Palm Kernel Shell Ash (PKSA) in concrete to assess the compressive strength and discussed that the use of PKSA as a partial replacement for cement in concrete, at lower volume of replacement, enhances the reduction of cement usage in concrete, thereby reducing production cost. Authors in [17] also studied the effect of fly ash. They used a dosage of fly ash from $0 \%-30 \%$ and quarry dust. From the obtained results, they concluded that the combined use of quarry dust and fly ash showed improvement in strength while reducing the environmental impact.

From the above discussion it may be observed that the use of fly ash as cementitious material, particularly in concrete made with partial replacement of coarse aggregates from demolished concrete, is very little and the scattering of results indicates that more work is required in order to have clear understanding of the combined effects of the materials on the strength properties of concrete. Therefore, this research work proposes the study of the effects of the addition of fly ash as replacement of cement on the compressive strength of recycled aggregate concrete (green concrete).

\section{MATERIALS AND TESTING}

Ordinary Portland cement (Pak land) was used in the mixes. Fine aggregates (hill sand) were obtained from the local market. The sand was sieved to remove lumps and larger particles before used in the concrete mixes. A demolished 2story reinforced concrete building in Nawabshah was the source of demolishing waste. The large blocks were hammered to produce coarse aggregates of maximum size equal to $25 \mathrm{~mm}$. After removing the unwanted material, the aggregates were washed and dried. Conventional coarse aggregates of the same size, obtained from the local market, were also washed and dried. The fly ash used in the current work was class C fly ash obtained from the Thar Power Plant. It was used in percentages of $0 \%, 2.5 \%, 5 \%, 7.5 \%$ and $10 \%$ by weight as replacement of cement. Figure 1 shows photos of the materials. Sieve analysis of both of the aggregates, conventional and recycled was done following the standard procedure to ensure well graded aggregates in the concrete mix (Figure 2). Coarse aggregates from demolishing waste and conventional coarse aggregates were used in $50 \%-50 \%$ ratio following the recommendations of
[18]. All the ingredients were mixed in 1:2:4 proportions with 0.5 water-cement ratio. A total of six concrete mixes were prepared. In four concrete mixes, fly ash (FA) and recycled aggregates (RA) from demolishing waste were used. In one mix only demolishing waste as coarse aggregates was used, and one concrete mix was prepared with all-conventional ingredients (control). The batching of all the mixes was done by weight in a concrete mixer. The water used was obtained from the local water supply and had a $\mathrm{pH}$ value equal to 6.7 .

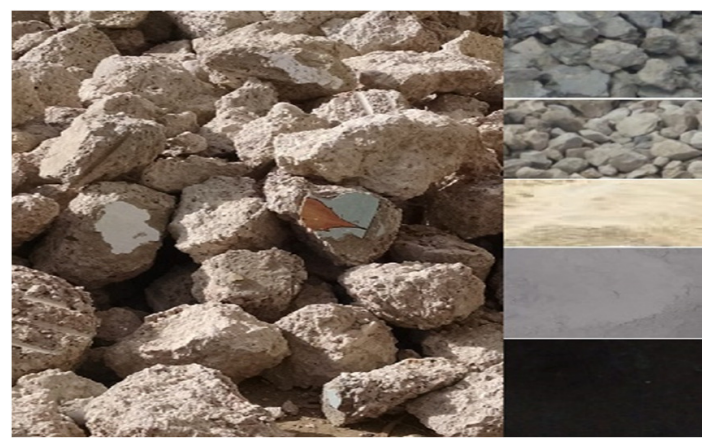

Fig. 1. Concrete ingredients: Large blocks of old concrete, recycled coarse aggregates after sizing, fine aggregates, and fly ash

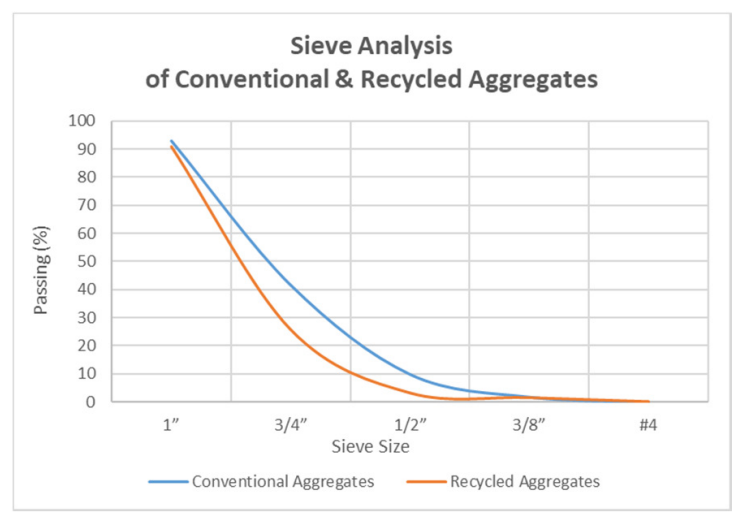

Fig. 2. Aggragates sieve analysis

\section{A. Workability}

To check the workability of concrete slump cone test was done for all concrete mixes. The test was performed following the standard procedure prescribed by the relevant testing standard. The obtained results are given in Table I.

TABLE I. SLUMP CONE TEST RESULTS

\begin{tabular}{|c|c|c|}
\hline Batch No & Description & Slump (mm) \\
\hline $\mathbf{1}$ & Conventional concrete & 23.0 \\
\hline $\mathbf{2}$ & $0 \%$ FA \& 50\% RA & 15.0 \\
\hline $\mathbf{3}$ & $2.5 \%$ FA \& 50\% RA & 16.3 \\
\hline $\mathbf{4}$ & $5 \%$ FA \& 50\% RA & 16.0 \\
\hline $\mathbf{5}$ & $7.5 \%$ FA \& 50\% RA & 15.8 \\
\hline $\mathbf{6}$ & $10 \%$ FA \& 50\% RA & 14.9 \\
\hline
\end{tabular}

\section{B. Preparing and Curing of Specimens}

From each concrete mix, three cylinders of standard size $6 " \times 12$ " were prepared. Mould preparation, pouring of concrete and compaction was done in accordance with ASTM 943-17. 
After 24 hours, the specimens were demoulded and left to airdry. All the specimens were cured by fully immersing in potable water for 28 days. Figures 3 and 4 show the specimens after drying and during curing respectively.

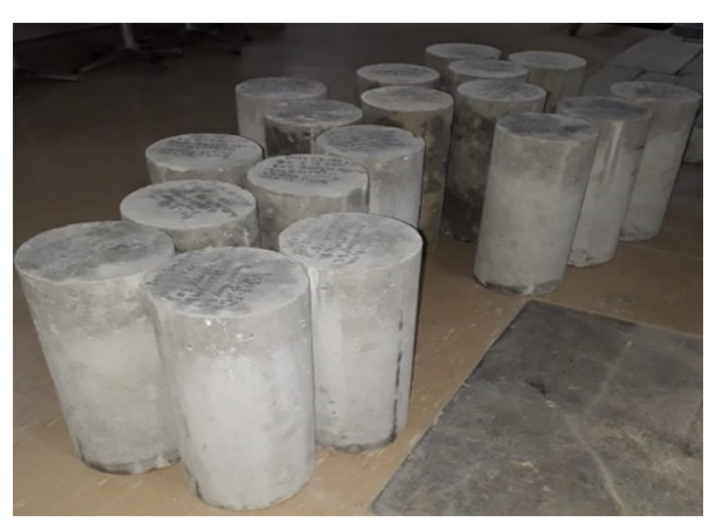

Fig. 3. Concrete cylinders

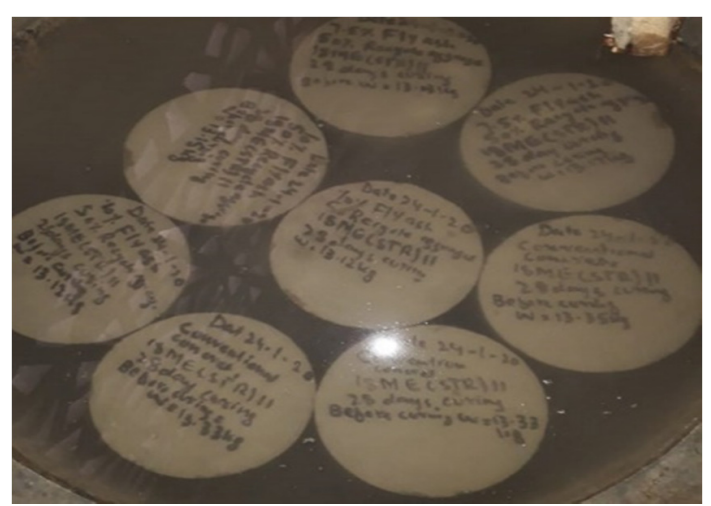

Fig. 4. Curing of specimens

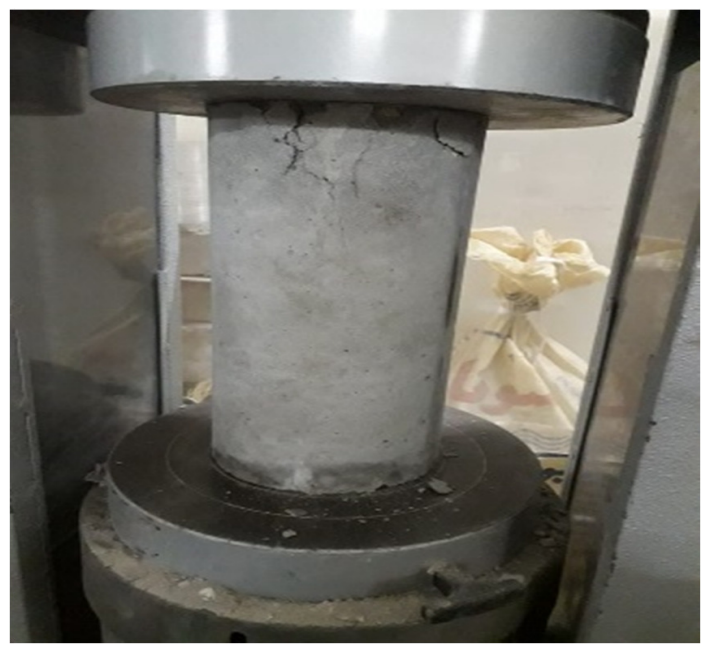

Fig. 5. Strength testing

\section{Compressive Strength}

After the completion of curing time, the specimens were air dried for 24 hours. Then, the test for compressive strength was performed in a Universal Testing Machine (UTM). The UTM was set to apply the load at a rate of $0.5 \mathrm{kN} / \mathrm{sec}$. The load was increased until failure (Figure 5). The compressive strength computed from the failure load and correctional dimensions of the specimens was recorded and is listed in Table II.

TABLE II. COMPRESSIVE STRENGTH RESULTS

\begin{tabular}{|c|c|c|c|c|c|}
\hline \multirow{2}{*}{$\begin{array}{c}\text { Batch } \\
\text { No }\end{array}$} & \multirow{2}{*}{ Description } & Load & \multicolumn{3}{|c|}{ Compressive strength } \\
\hline & & $\mathbf{k N}$ & $\mathrm{N} / \mathrm{mm}^{2}$ & Psi & $\mathrm{kg} / \mathrm{cm}^{2}$ \\
\hline \multirow{3}{*}{1} & \multirow{3}{*}{$\begin{array}{l}\text { Conventional } \\
\text { concrete }\end{array}$} & 493.2 & 27.06 & 3923.37 & 275.99 \\
\hline & & 515.1 & 28.26 & 4097.58 & 288.24 \\
\hline & & 510.7 & 28.02 & 4062.58 & 285.78 \\
\hline \multirow{3}{*}{2} & \multirow{3}{*}{$0 \%$ FA \& $50 \%$ RA } & 456.9 & 25.07 & 3634.61 & 255.68 \\
\hline & & 366.7 & 20.12 & 2917.07 & 205.20 \\
\hline & & 394.9 & 21.66 & 3141.40 & 220.98 \\
\hline \multirow{3}{*}{3} & \multirow{3}{*}{$\begin{array}{c}2.5 \% \text { FA \& } 50 \% \\
\text { RA }\end{array}$} & 391.6 & 21.48 & 3115.15 & 219.13 \\
\hline & & 395.6 & 21.70 & 3146.97 & 221.37 \\
\hline & & 380.9 & 20.90 & 3030.03 & 213.15 \\
\hline \multirow{3}{*}{4} & \multirow{3}{*}{$5 \%$ FA \& $50 \%$ RA } & 412.1 & 22.61 & 3278.22 & 230.61 \\
\hline & & 494.6 & 27.13 & 3934.51 & 276.77 \\
\hline & & 448.7 & 24.62 & 3569.38 & 251.09 \\
\hline \multirow{3}{*}{5} & \multirow{3}{*}{$\begin{array}{c}7.5 \% \text { FA \& } 50 \% \\
\text { RA }\end{array}$} & 484.9 & 26.60 & 3857.34 & 271.34 \\
\hline & & 406.9 & 22.32 & 3236.86 & 227.70 \\
\hline & & 360.6 & 19.78 & 2868.55 & 201.79 \\
\hline \multirow{3}{*}{6} & \multirow{3}{*}{$10 \%$ FA \& $50 \%$ RA } & 393.0 & 21.56 & 3126.29 & 219.92 \\
\hline & & 397.5 & 21.81 & 3162.08 & 222.44 \\
\hline & & 305.2 & 16.74 & 2427.84 & 170.79 \\
\hline
\end{tabular}

\section{RESULTS AND DISCUSSION}

The sieve analysis results shown in Figure 2 show that both aggregates confirm the standard requirements of well graded aggregates. The trend of both curves is almost similar, with minor differences in range values over a sieve. The slump test results of the FA and RA mixes were less than that of the conventional concrete. The percentile reduction in slump of the tested proposed mixes is shown in Figure 6. It may be observed that increasing dosage of FA increased the reduction in the slump value of the mix. Minimum reduction in slump was observed for $2.5 \%$ and $5 \%$ replacement levels of cement with FA and was about $30 \%$. This shows that the mix water requirements are more with FA. This should be considered while selecting the water/cement ratio for the mix otherwise more mechanical effort or admixture will be required to maintain the required workability.

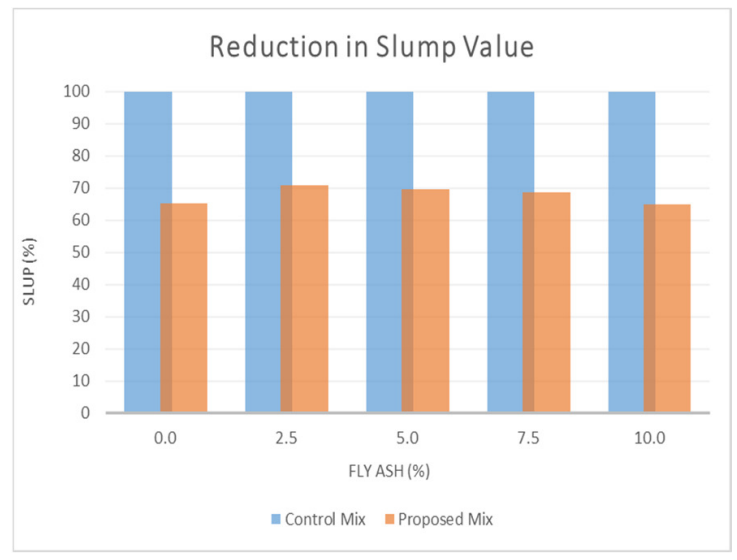

Fig. 6. Percentile reduction of slump 
The compressive strength of all specimens presented above is averaged and compared with the average compressive strength of control mix in Figure 7. The percentile reduction of average compressive strength with respect to control mix and the mix cast with $50 \%$ recycled aggregates is shown in Table III. It may be observed that the addition of 5\% FA along with $50 \%$ RA gives maximum compressive strength among all proposed mixes. The reduction in the average strength in comparison to the control mix is equal to $10.77 \%$. This reduction is comparable with the result presented in [13]. Therefore, $5 \%$ of the fly ash is the optimum dosage of this material, and it can comfortably be used in new concrete along with $50 \%$ recycled aggregates from demolishing waste. However, the concrete may initially be used in low load areas as it has about $11 \%$ less strength than conventional concrete.

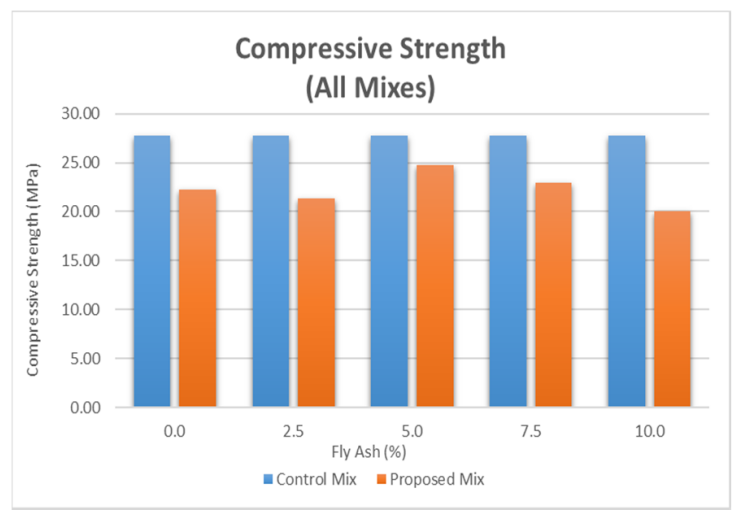

Fig. 7. Average compressive strength

TABLE III. AVERAGE COMPRESSIVE STRENGTH REDUCTION

\begin{tabular}{|c|c|c|c|}
\hline $\begin{array}{c}\text { Batch } \\
\text { No }\end{array}$ & Description & \multicolumn{2}{c|}{ Error (\%) } \\
\hline 1 & Conventional concrete & 0.00 & - \\
\hline 2 & $0 \%$ FA \& 50\% RA & -19.78 & 0.00 \\
\hline 3 & $2.5 \%$ FA \& 50\% RA & -23.10 & -4.14 \\
\hline 4 & $5 \%$ FA \& 50\% RA & -10.77 & 11.24 \\
\hline 5 & $7.5 \%$ FA \& 50\% RA & -17.55 & 2.78 \\
\hline 6 & $10 \%$ FA \& 50\% RA & -27.87 & -10.08 \\
\hline
\end{tabular}

\section{CONCLUSION}

In this research paper, fly ash and recycled aggregates obtained from demolishing waste were used in concrete mixes and their effect on the compressive strength of concrete was studied. Workability and compressive strength of the prepared mixed were measured and compared with all-conventional concrete's. The results show that slump value reduces with increase in fly ash dosage, hence the concrete requires more mechanical effort in compaction or use of admixture to maintain its workability. Compressive strength results showed that $5 \%$ dosage of fly ash is optimum as it gives minimum reduction (about 11\%) in compressive strength among all studied mixes. This concrete can be used in new constructions, but it is proposed to be initially utilized in low load areas.

\section{REFERENCES}

11] B. A. Memon, "Recent development on use of demolished concrete as coarse aggregates", International Journal of Emerging Technology and Innovative Engineering, Vol. 2, No. 1, pp. 1-16, 2016

[2] Z. Tafheem, S. Khusru, S. Nasrin, "Environmental impact of green concrete in practice", International Conference on Mechanical Engineering and Renewable Energy, Chittagong, Banglades, December 22-24, 2011

[3] B. Suhendro, "Toward green concrete for better sustainable environment", Procedia Engineering, Vol. 95, pp. 305-320, 2014

[4] V. S. Vairagade D. K. Parbat, S. A. Dhale, "Fly ash as sustainable material for green concrete: A state-of-art", International Journal of Research in Engineering, Science \& Technology, Vol. 1, No. 2, pp. 1724, 2015

[5] N. M. Altwair, S. Kabir, "Green concrete structures by replacing cement with pozzolanic materials to reduce greenhouse gas emissions for sustainable environment", $6^{\text {th }}$ International Engineering and Construction Conference, Cairo, Egypt, June 28-30, 2010

[6] S. C. K. Bendapudi, P. Saha, "Contribution of fly ash to the properties of mortar and concrete", International Journal of Earth Sciences and Engineering, Vol. 4, No. 6, pp. 1017-1023, 2011

[7] N. M. Altwair, S. Kabir, "Reducing environmental impacts through green concrete technology", $3^{\text {rd }}$ Technology and Innovation for Sustainable Development International Conference, Khon Kaen University, Thailand, March 4-6, 2010

[8] C. Edvardsen, K. Tollose, "Environmentally "green" concrete structures", FIB Symposium: Concrete and Environment, Berlin, Germany, October 3-5, 2001

[9] P. Nath, P. Sarker, "Effect of fly ash on the durability properties of high strength concrete", Procedia Engineering, Vol. 14, pp.1149-1156, 2011

[10] A. Jatale, K. Tiwari, S. Khandelwal, "Effects on compressive strength when cement is partially replaced by fly ash", IOSR Journal of Mechanical and Civil Engineering, Vol. 5, No. 4, pp. 34-43, 2013

[11] S. Wang, V. C. Li, "Engineered cementitious composites with highvolume fly ash", ACI Materials Journal, Vol. 104, No. 3, pp. 233-241, 2007

[12] B. S. Kumar, V. P. Arunachalam, R. Thenmozhi, T. S. Vadive, "Effect on strength characteristics of low calcium fly ash based geopolymer concrete: An initiative towards green concrete", International Journal of Applied Environmental Sciences, Vol. 11, No. 1, pp. 173-182, 2016

[13] C. M. Helepciuc, M. Barbuta, D. Babor, "Investigations on a green concrete obtaining through a partial cement Replacement by fly ash", Advances in Environmental Sciences, Vol. 9, No. 3, pp. 207-214, 2017

[14] S. A. K. Reddy, K. C. Reddy, "Effect of fly ash on strength and durability parameters of concrete", International Journal of Science and Research, pp. 2319-7064, 2013

[15] N. Bheel, A. W. Abro, I. L. Shar, A. A. Dayo, S. Shaikh, Z. H. Shaikh, "Use of rice husk ash as cementitious material in concrete", Engineering, Technology \& Applied Science Research, Vol. 9, No. 3, pp. 4209-4212, 2019

[16] D. F. A. Olutoge, H. A. Quadri, O. S. Olafusi, "Investigation of the strength properties of palm kernel shell ash concrete", Engineering, Technology \& Applied Science Research, Vol. 2, No. 6, pp. 315-319, 2012

[17] A. Krishnamoorthi, G. M. Kumar, "Properties of green concrete mix by concurrent use of fly ash and quarry dust", IOSR Journal of Engineering, Vol. 3, Noi. 8, pp. 48-54, 2013

[18] M. Oad, B. A. Memon, "Compressive strength of concrete cylinders using coarse aggregates from old concrete", 1st National Conference on Civil Engineering (Modern Trends and Advancements), Pakistan, April $28-29,2014$ 